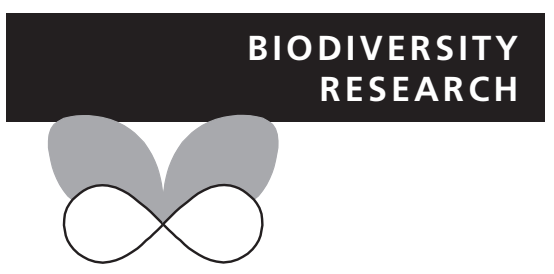

\title{
Native-range habitats of invasive plants: are they similar to invaded-range habitats and do they differ according to the geographical direction of invasion?
}

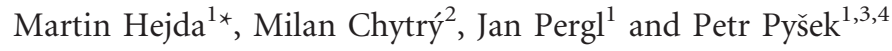

\begin{abstract}
${ }^{1}$ Department of Invasion Ecology, Institute of Botany, Academy of Sciences of the Czech Republic, CZ-252 43 Prìhonice, Czech Republic, ${ }^{2}$ Department of Botany and Zoology, Masaryk University, CZ-611 37 Brno, Czech Republic, ${ }^{3}$ Department of Ecology, Faculty of Science, Charles University in Prague, CZ-128 44 Prague, Czech Republic, ${ }^{4}$ Centre for Invasion Biology, Stellenbosch University, Matieland 7602, South Africa
\end{abstract}

${ }^{*}$ Correspondence: Martin Hejda, Department of Invasion Ecology, Institute of Botany, Academy of Sciences of the Czech Republic, CZ-252 43 Průhonice, Czech Republic. E-mail: martin.hejda@ibot.cas.cz

\begin{abstract}
Aim Habitat types are involved in shaping biological traits of their resident native species and thus they determine, to a large extent, in which habitats particular species will succeed if invading outside their native range. However, the correspondences between habitats that invasive aliens occupy in the native and invaded ranges are poorly known. We explore the relationships between (1) habitats of invasive species in their native and invaded ranges and (2) nativerange habitats and the direction of invasion (from/to Europe; from/to the Old World).
\end{abstract}

Location Global.

Methods Descriptions of native- and invaded-range habitats of 286 invasive species were extracted from the literature and transformed into 12 habitat types. The differences between native-range habitats according to the direction of invasion and between habitats occupied in the native and invaded ranges were tested by log-linear models and deletion tests.

Results Most frequent invaders were species confined to forests (98 species), riparian habitats (80), grasslands (80) and man-made habitats (73) in their native ranges. Native-range habitats differed between species invading from and to Europe (110 and 41, respectively) as well as between species invading from and to the Old World (213 and 75, respectively). Grasslands were the most overrepresented native-range habitat for species invading from Europe compared to species invading Europe; wetlands were the most overrepresented native-range habitats for species invading the Old World compared to species invading from the Old World. Many species that originated from forests invade grasslands, and, conversely, many grassland species invade open forests.

Main conclusions European grassland species are much more successful as world-wide invaders than grassland species from other continents invading Europe, and New World wetland species invading the Old World are more successful than wetland species invading from the Old World. Successful invaders are adapted to a broad spectrum of successional phases ranging from grasslands to forests.

\section{Keywords}

Biological invasions, direction of invasion, habitat invasions, invaded-range habitats, native-range habitats, plant invasions, source-area approach.

\section{INTRODUCTION}

A habitat is generally referred to as the environment of species, determined by a combination of abiotic and biotic factors. Recent studies have demonstrated that habitat characteristics play an important role in determining the patterns of invasions by alien plant species (Catford et al., 2012; Pyšek \& Chytrý, 2014). However, habitats in the invaded 
ranges have been the main focus of research so far (Stohlgren et al., 1999, 2006; Chytrý et al., 2005, 2008b; Vilá et al., 2007; Affre et al., 2010; Pyšek et al., 2010a, 2012), including studies of their invasibility versus actual level of invasion (Chytrý et al., 2008a,b). Native-range habitats have been studied rarely, for example as potential predictors of invasion success (Hejda et al., 2009), or when attempting to relate the invasion success of species from particular habitats to the level of invasion of analogous habitats in the invaded ranges (Kalusová et al., 2013). The similarity between habitat types of alien plant species in their native versus invaded ranges has been addressed in several case studies, but these mostly focused on single invasive species (see for example Otte et al., 2007). Various explanations for the observed shifts in habitat preferences or tolerances between the native and invaded ranges have been suggested, such as the release from natural enemies (DeWalt et al., 2004) or genotypic and phenotypic plasticity. This may result in the ability of species to thrive in a broad spectrum of conditions and possibly also in the ability to successfully colonize different habitat types compared to those occupied in the native range (Geng et al., 2007).

The characteristics of the native-range habitats can provide general information about the pre-adaptations of successful invaders. In addition, the level of correspondence between native- and invaded-range habitats can provide an estimate of the relative importance of pre-adaptations compared to postinvasion shifts in habitat preferences of the invading species. Using a large number of plant species invasive world-wide, this paper addresses characteristics of native-range habitats and their correspondence with habitats in the invaded ranges at the global scale, an issue that has been rarely addressed so far (but see Hejda et al., 2009; Kalusová et al., 2013).

Potential interactions between the origin of invasive species from particular native-range habitats and their geographical direction of invasion represent another interesting issue. Species with different traits and adaptations can be expected to be succesful invaders in different areas of the world, depending on climate in both ranges, history of human migration, patterns of international trade, land use and human impacts on vegetation (Pyšek et al., 2010b). Massive spread of invasive plants is often considered to be associated with changes in disturbance regimes, be it sudden large disturbances or, in contrast, declines in the periodicity and intensity of regular disturbance events (di Castri, 1989; Hobbs \& Huenneke, 1992; Alpert et al., 2000; Davis et al., 2000; Davis \& Pelsor, 2001; but see Moles et al., 2012). In general, Europe is considered to be more a source of invasive species rather than their acceptor (di Castri, 1989; Pyšek, 1998; Stohlgren et al., 2011), and it is therefore possible that invasions play a different role in the landscape dynamics in Europe than in other parts of the world. In Europe, the spread of invasive species can be associated both with disturbances of native vegetation and with a decline of long-term management, because the long-term stability of many European plant communities (e.g. secondary grasslands) depends on certain intensity and periodicity of human activities (Hufbauer et al., 2011; Seastedt \& Pyšek,
2011; Hejcman et al., 2013). In other parts of the world, invasions tend to be mostly associated with human-induced disturbances of natural vegetation (e.g. Hobbs \& Huenneke, 1992; Higgins \& Richardson, 1998; D’Antonio et al., 1999). For these reasons, it is possible that alien species coming from different habitat types (i.e. with different adaptations in the native range) are successful when invading Europe compared to the European species invading the rest of the world. Similar logic can be applied to species invading the Old World and the New World, two large areas that greatly differ in the history and intensity of human exploitation (di Castri, 1989).

Moreover, evolutionary and phylogenetic differences can be presumed to exist between species that originated outside versus inside Europe. For example, Australia is a refuge for archaic forms that have become extinct on other continents (Gentry, 1982). For this reason, Australian species exhibit a high degree of evolutionary naivety when confronted with weedy species with cosmopolitan distribution (Schlaepfer et al., 2005). This phenomenon is likely to be even more pronounced in case of islands such as New Zealand. Native species of New Zealand have been shown to be much less successful when competing with invasive weeds than species originating in Europe (Hejda, 2013). Another evolutionary background may also differentiate species from Eurasia and from North America. Due to the north-south arrangement of most North American mountain ranges (Cascades, Rocky Mountains, Appalachian Mountains), it was relatively easy for North American species to migrate north and south and, to some extent, balance the climatic changes associated with glaciation. On the other hand, large-scale east-west migrations were possible for Eurasian species, which have been therefore confronted with many competitive strategies and many have developed a superior competitive strength (di Castri, 1989). For these reasons, European and Eurasian species can be presumed to differ in their adaptations and competitive abilities compared to species from, for example, North America or Australia, which may also influence their success and habitat affiliations in the invaded ranges.

This paper aims to (1) identify and rank the native-range habitats of the world's most widespread invasive alien plant species; (2) find out whether the native-range habitats differ among species invading in various geographical directions from Europe versus to Europe and from the Old World versus to the Old World; (3) find out whether the differences in native-range habitats are reflected in the representation of basic life forms (woody versus herbaceous) and life histories (annual versus perennial); and (4) explore the correspondence between habitats in the native and invaded ranges.

\section{METHODS}

\section{Data sources, species selection and classification system}

Data were extracted from Weber (2003), a compendium that lists 450 species considered as the worst invaders world-wide, 
focusing on those that are known to be invasive in semi-natural habitats rather than those that only grow in man-made habitats. For these reasons, the list of species did not include many widespread agricultural weeds. Only those species were selected for which the description of both native- and invaded-range habitats was detailed enough. Many nativerange and a few invaded-range habitat descriptions from Weber (2003) were supplemented with habitat descriptions obtained from various online sources (see Appendix S1 in Supporting Information). This resulted in a set of 286 species (63.6\% of the total of 450 covered by Weber, 2003).

A major task was to transform the unstructured verbal descriptions of habitats into categories that would allow for classification of species' occurrence in various types of native- and invaded-range habitats. A relatively coarse classification was adopted to avoid misinterpretations of fine-scale habitat descriptions and to account for species originating from and invading to various climatic zones and vegetation types. Taking all these requirements into account, we developed a classification with 12 habitat types that could be consistently applied across the initially disparate descriptions (Table 1). A matrix of species and habitat types in both native and invaded ranges was created, with binary $(0 / 1)$ affiliations of species to particular habitat types. Most species were assigned to more than one habitat type. For example, when species' native-range habitats were described as 'wetlands, wet meadows and riparian scrubs', it was assigned to grassland, wetland, riparian and scrub habitat types. For these reasons, the sum of species-habitat affiliations $(n=688$ in the native ranges and $n=933$ in the invaded ranges) considerably exceeds the total number of species $(n=286)$. The nomenclature of plant taxa is standardized according to Weber (2003) and Kubát et al. (2002).

\section{Data analysis}

The differences in native-range habitat types of (1) European species invading world-wide versus species invading Europe and (2) species invading from the Old World versus species invading the Old World were tested using a log-linear model, assuming a Poisson distribution of errors (Crawley, 2007: p. 527-569). Species' frequencies in habitat types were used as a response variable. The interaction term between the factor 'native-range habitat' (with each level representing a particular native-range habitat type) and the factor 'direction of invasion' (species invading from versus to Europe; species invading from the Old World versus to the Old World) was tested. This interaction was used as a measure of differences in the native-range habitat types between species invading in the two opposite directions. There were 110 European species invading world-wide; 41 invading Europe; 213 invading from the Old World; and 75 invading the Old World. The 'Old World' was defined as Eurasia (temperate and tropical), Africa (including Madagascar and surrounding islands in the Atlantic ocean: Azores, Canaries, Madeira and Cape Verde). The 'New World' included North, Central and South America, Caribbean islands, Pacific islands, Australia and New Zealand. Some species invaded different areas within the same continent. For example, there were 13 species native to Europe and invasive to another part of Europe. These cases have been excluded from the analysis of the interaction between native-range habitats and geographical direction of invasions.

Using simple contingency tables, we also tested whether the representation of basic life forms (woody versus herbaceous species) and life histories (annual versus perennial) differed between the geographical directions of invasions mentioned above.

The correspondence between native- and invaded-range habitats of species was tested using a log-linear model with Poisson errors and with 'habitat types' and 'native-versusinvaded range' as factor variables. The interaction between both factors indicated whether the species' frequencies in habitat types differed for the native versus invaded ranges.

The significances of all these interaction terms were tested by deletion tests, which compared the differences in residual deviance between the log-linear models with and without the interaction term using the chi-square test (Crawley, 2007). The results of the test were interpreted based on the most

Table 1 Habitat types used in this study with brief descriptions

\begin{tabular}{ll}
\hline Habitat type & Description \\
\hline $\begin{array}{l}\text { 1. Forests } \\
\text { 2. Open forests }\end{array}$ & Closed vegetation dominated by deciduous or evergreen trees \\
3. Scrub & Shrublands maintained by environmental stress (aridity) or disturbance \\
4. Grasslands & Open graminoid-dominated habitats maintained either by climate (steppes, prairies, savannas) or land use (grazing, mowing) \\
& or combination of both \\
5. Sandy & Dunes and other habitats on unstable sandy substrate, stressed by low nutrients, drought and disturbed by sand movement \\
6. Rocky & Cliffs and rock outcrops with very shallow or no soil \\
7. Dryland & Habitats in which drought stress limits vegetation development \\
8. Saline & A mosaic of wetlands, grasslands, tall-forb stands, scrub and woodlands in stream corridors \\
9. Riparian & Sites with permanent or seasonal influence of moisture, ranging from oligotrophic to eutrophic \\
10. Wetland & Water bodies and streams with submerged and floating plant species \\
11. Aquatic & Habitats created by humans or where human factor is the main shaping force \\
12. Man-made &
\end{tabular}


disproportional cells (= habitat types). The most disproportional cells (habitat types) were identified by comparing the share of each habitat type between the compared subgroups of species: those invading from versus to Europe; from versus to the Old World; native versus invaded ranges. Multiple comparisons among the levels (habitat types) using the G-tests (Pergl et al., 2012) were not possible due to low numbers of cases and therefore also low expected values in many of the cells, which was due to relatively large number of habitat categories analysed. All analyses were processed in R software (R Development Core Team, 2011).

\section{RESULTS}

\section{Native-range habitats}

Most of the invasive alien plants in the dataset originated from Africa (140 species of $286 ; 49 \%$ ) and temperate Asia (132 species; 46\%). Australia and New Zealand were the most invaded areas (186 species; 65\%), followed by North America (141 species; 49\%). Of the 140 species native to Africa, most species $(121 ; 86 \%)$ were invasive in Australia and New Zealand (Table 2).

The greatest number of invasive species had their nativerange habitats in forests, followed by riparian, grassland and man-made habitats. By contrast, the smallest proportions of invasive alien plants came from aquatic, saline or dryland habitats (Fig. 1).

\section{Interaction between native-range habitats and the geographical direction of invasion}

The native-range habitats differed according to the geographical direction of invasion, both for species invading from Europe versus to Europe and from the Old World versus to the Old World, as shown by the significant interactions between the factors 'native-range habitats' and 'direction of invasion' (d.f. $=11$, chi $^{2}=21.426, P=0.029$; and d.f. $=11$, $\mathrm{chi}^{2}=31.917, P<0.001$, respectively).

Grassland as a native-range habitat showed the greatest disproportion when species invading from and to Europe were compared. For European species invading world-wide, grasslands made $17.4 \%$ of all species-to-habitat affiliations, but only $6.0 \%$ for species invading Europe (Table 3). Wetlands as native-range habitats were most disproportionally represented in the Old World versus New World comparison, with $15.2 \%$ of species-to-habitat affiliations of species native to the New World and invading the Old World and only $8.6 \%$ of those native to the Old World and invading the New World (Table 3).

Species invading from versus to Europe and from versus to the Old World also differed in the representation of basic life forms and life histories. Annuals and herbaceous species were more represented among species invading from Europe than among those invading to Europe (d.f. $=1$, chi $^{2}=4.499$, $P=0.034$ and d.f. $=1$, chi $^{2}=4.335, P=0.037$, respectively), and annuals were also more represented among species invading from the Old World than among those invading to

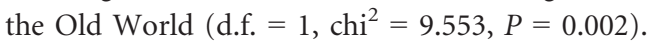

\section{Correspondence between native- and invaded-range habitats}

The significant interaction term between the factors 'habitat' and 'native-invaded range' revealed that frequencies of species within the types of native-range habitats differed from those within the invaded ranges (d.f. $=11$, chi $^{2}=39.94$, $P<0.001)$. Grasslands were most disproportionally represented among the habitat types, with $11.6 \%$ of all species-tohabitat affiliations in the native ranges and $16 \%$ in the invaded ranges.

The correspondence between the native- and invaded-range habitats was complex, because species of most native-range habitats invaded various, in some cases rather different, habi-

Table 2 Native and invaded ranges of the selected invasive species $(n=286)$, with numbers representing species native to (rows) and invading particular area (columns). The numbers do not sum up to the totals, because a single species can be native or invasive to more than one area

\begin{tabular}{|c|c|c|c|c|c|c|c|c|c|c|}
\hline \multirow[b]{2}{*}{ Native range } & \multicolumn{10}{|c|}{ Invaded range } \\
\hline & Europe & Africa & $\begin{array}{l}\text { Temperate } \\
\text { Asia }\end{array}$ & $\begin{array}{l}\text { Tropical } \\
\text { Asia }\end{array}$ & $\begin{array}{l}\text { North } \\
\text { America }\end{array}$ & $\begin{array}{l}\text { South } \\
\text { America }\end{array}$ & $\begin{array}{l}\text { Tropical } \\
\text { America }\end{array}$ & $\begin{array}{l}\text { Australia and } \\
\text { New Zealand }\end{array}$ & $\begin{array}{l}\text { Pacific } \\
\text { islands }\end{array}$ & $\begin{array}{l}\text { Total in the } \\
\text { native range }\end{array}$ \\
\hline Europe & 13 & 30 & 5 & 9 & 70 & 30 & 18 & 100 & 28 & 119 \\
\hline Africa & 18 & 36 & 6 & 11 & 76 & 33 & 25 & 121 & 36 & 140 \\
\hline Temperate Asia & 16 & 34 & 0 & 5 & 83 & 25 & 16 & 97 & 29 & 132 \\
\hline Tropical Asia & 8 & 26 & 1 & 0 & 46 & 14 & 15 & 35 & 21 & 67 \\
\hline North America & 13 & 18 & 2 & 8 & 7 & 5 & 2 & 21 & 10 & 38 \\
\hline Tropical America & 12 & 26 & 2 & 11 & 15 & 7 & 4 & 20 & 17 & 40 \\
\hline South America & 6 & 15 & 2 & 4 & 11 & 1 & 2 & 16 & 7 & 25 \\
\hline Australia and New Zealand & 7 & 19 & 2 & 0 & 17 & 3 & 4 & 6 & 9 & 34 \\
\hline Pacific islands & 1 & 3 & 1 & 0 & 8 & 2 & 3 & 2 & 2 & 11 \\
\hline Total in the invaded range & 57 & 99 & 11 & 24 & 141 & 34 & 45 & 186 & 68 & \\
\hline
\end{tabular}




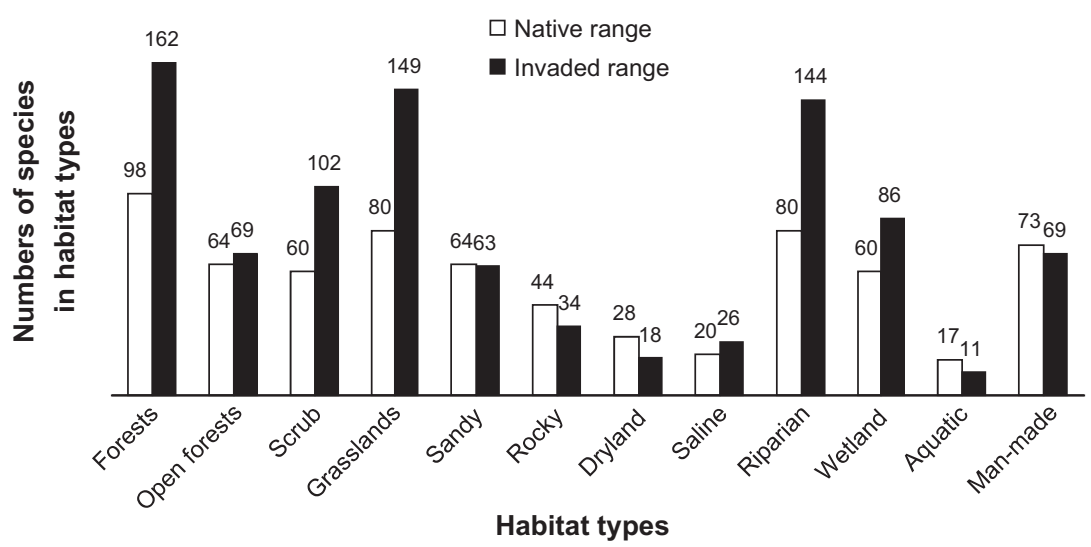

Figure 1 Numbers of species affiliated with habitat types in their native and invaded ranges.

Table 3 Numbers of species affiliated with native-range habitat types of European species invading elsewhere $(n=110)$, species with origin outside Europe and invading Europe $(n=41)$, species originating in the Old World $(n=213)$ and in the New World $(n=75)$. Percentages are calculated from the total numbers of affiliations of species into habitat types within that particular category - invading from/to Europe; invading from the Old World/to the Old World. The differences in percentages shown for each habitat type refer to comparison of (1) European species invasive elsewhere versus species invading Europe and (2) species invading from the Old World and to the Old World

\begin{tabular}{|c|c|c|c|c|c|c|c|c|c|c|}
\hline $\begin{array}{l}\text { Habitat } \\
\text { category }\end{array}$ & $\begin{array}{l}\text { From } \\
\text { Europe }\end{array}$ & $\%$ & To Europe & $\%$ & $\begin{array}{l}\text { From Europe } \\
\text { minus to Europe } \\
\text { difference }(\%)\end{array}$ & $\begin{array}{l}\text { From the } \\
\text { Old World }\end{array}$ & $\%$ & $\begin{array}{l}\text { To the } \\
\text { Old World }\end{array}$ & $\%$ & $\begin{array}{l}\text { From the Old World } \\
\text { minus to the Old } \\
\text { World difference (\%) }\end{array}$ \\
\hline Forests & 31 & 10.4 & 12 & 14.3 & -3.9 & 69 & 12.7 & 30 & 18.3 & -5.6 \\
\hline Open forests & 17 & 5.7 & 10 & 11.9 & -6.2 & 48 & 8.8 & 16 & 9.8 & -1.0 \\
\hline Scrub & 30 & 10.1 & 4 & 4.8 & 5.3 & 46 & 8.5 & 8 & 4.9 & 3.6 \\
\hline Grasslands & 52 & 17.4 & 5 & 6.0 & 11.4 & 70 & 12.9 & 14 & 8.6 & 4.3 \\
\hline Sandy & 25 & 8.4 & 8 & 9.5 & -1.1 & 54 & 9.9 & 13 & 7.9 & 2.0 \\
\hline Rocky & 22 & 7.4 & 6 & 7.1 & 0.3 & 37 & 6.8 & 4 & 2.4 & 4.4 \\
\hline Dryland & 15 & 5.0 & 3 & 3.6 & 1.4 & 22 & 4.0 & 4 & 2.4 & 1.6 \\
\hline Saline & 8 & 2.7 & 4 & 4.8 & -2.1 & 17 & 3.1 & 5 & 3.0 & 0.1 \\
\hline Riparian & 26 & 8.7 & 11 & 13.1 & -4.4 & 63 & 11.5 & 22 & 13.4 & -1.9 \\
\hline Wetlands & 26 & 8.7 & 10 & 11.9 & -3.2 & 47 & 8.6 & 25 & 15.2 & -6.6 \\
\hline Aquatic & 4 & 1.3 & 4 & 4.8 & -3.5 & 8 & 1.4 & 11 & 6.7 & -5.3 \\
\hline Man-made & 42 & 14.1 & 7 & 8.3 & 5.8 & 63 & 11.6 & 12 & 7.3 & 4.3 \\
\hline
\end{tabular}

tats in the invaded ranges (Table 4). For example, species originating from scrub frequently invaded riparian habitats (including riparian scrub) and grasslands, while species originating from wetlands invaded riparian habitats (including riparian wetlands) and grasslands as well. Conversely, species originating from riparian habitats invaded grasslands and scrub, and grassland species often invaded riparian habitats (including riparian grasslands), but also open woodlands. Forest species invaded riparian habitats (including riparian forests), but also grasslands, while species originating from open woodland massively invaded forests and riparian habitats, but also man-made habitats (Table 4 ).

\section{DISCUSSION}

Within the current dataset, Africa was identified as the source region of most of the invaders, followed by temperate
Asia and Europe, while Australia and New Zealand, followed by North America, were identified as the most invaded regions. Species of African and European origin (121 and 100 species, respectively) were identified as most frequently invading Australia and New Zealand. This pattern may reflect (1) close climatic match between large areas in Africa and Australia (Thuiller et al., 2005), (2) the world-wide spread of European species as a result of the European expansion and (3) generally high levels of invasion in both Australia and New Zealand, which may be partly due to the insular character of these areas (Mooney \& Drake, 1989; Williams \& West, 2000).

An important lesson learned from this study is that invasive species differ in their native-range habitat types according to the geographical direction of invasions - both when comparing species invading from Europe versus to Europe and from Old World versus to Old World. The overrepre- 
Table 4 Correspondence between native- and invaded-range habitat types for all the studied invasive plant species $(n=286)$. For each habitat type in the native range (rows), the numbers of species in the invaded ranges are shown (columns). The table shows only cases when a particular habitat type is not occupied in the native range, representing 'net' transitions between habitats, associated with invasions. For example, 30 species with 'scrub' and without 'riparian' affiliation to the native-range habitats invaded 'riparian habitats' in the invaded ranges. The numbers on the diagonal, representing transitions between identical habitats in the native and invaded ranges (in parentheses), show the numbers of species originating in and invading to that particular habitat

\begin{tabular}{|c|c|c|c|c|c|c|c|c|c|c|c|c|}
\hline \multirow{2}{*}{$\begin{array}{l}\text { Habitat in the } \\
\text { native range }\end{array}$} & \multicolumn{12}{|c|}{ Habitat in the invaded range } \\
\hline & Forest & Open forest & Scrub & Grassland & Sandy & Rocky & Dryland & Saline & Riparian & Wetland & Aquatic & Man-made \\
\hline Forest & $0(77)$ & 23 & 19 & 28 & 10 & 8 & 8 & 6 & 41 & 12 & 0 & 15 \\
\hline Open forest & 29 & $0(31)$ & 15 & 17 & 6 & 7 & 2 & 2 & 18 & 8 & 0 & 18 \\
\hline Scrub & 21 & 10 & $0(31)$ & 22 & 9 & 5 & 2 & 1 & 30 & 5 & 1 & 9 \\
\hline Grasslands & 26 & 27 & 23 & $0(61)$ & 15 & 7 & 2 & 4 & 33 & 18 & 1 & 16 \\
\hline Sandy & 17 & 5 & 22 & 21 & $0(27)$ & 4 & 6 & 4 & 19 & 10 & 1 & 6 \\
\hline Rocky & 15 & 3 & 11 & 17 & 6 & $0(14)$ & 2 & 2 & 21 & 4 & 0 & 6 \\
\hline Dryland & 10 & 5 & 6 & 9 & 4 & 3 & $0(5)$ & 2 & 11 & 4 & 0 & 6 \\
\hline Saline & 3 & 1 & 4 & 4 & 5 & 0 & 1 & $0(12)$ & 6 & 1 & 0 & 2 \\
\hline Riparian & 12 & 10 & 19 & 20 & 8 & 6 & 2 & 5 & $0(46)$ & 13 & 1 & 13 \\
\hline Wetland & 12 & 6 & 10 & 16 & 6 & 2 & 1 & 3 & 17 & $0(41)$ & 1 & 5 \\
\hline Aquatic & 1 & 1 & 0 & 1 & 0 & 0 & 0 & 0 & 5 & 6 & $0(10)$ & 0 \\
\hline Man-made & 30 & 9 & 19 & 20 & 14 & 6 & 4 & 4 & 36 & 16 & 0 & $0(27)$ \\
\hline
\end{tabular}

sentation of European grassland species invading other continents compared to species invading Europe may be associated with introducing the European style of grassland land use and livestock as well as with direct introductions of grassland species for forage to the other continents. European grassland species invasive world-wide (for example Agrostis capillaris, A. stolonifera, Anthoxanthum odoratum, Arrhenatherum elatius, Bromus inermis, Carduus nutans, Centaurea stoebe, Dactylis glomerata, Echium plantagineum, Erodium cicutarium, Hieracium pilosella, Hypericum perforatum, Lotus corniculatus, Plantago lanceolata, Ranunculus repens and many others) are likely better adapted to intensive anthropogenic pressure than grassland species from other continents (Hejcman et al., 2013). At the same time, disturbed sites in European grasslands are usually colonized by native species, which may decrease the invasion success of species introduced from other continents (Seastedt \& Pyšek, 2011). Of course, this result can be biased by Europe having different areas of grasslands or different numbers of grassland species compared to other continents. However, this is not likely an explanation of the prevalence of grassland species invading from Europe compared to species invading Europe, because all continents included in this study contain large and species-rich grassland areas.

Concerning basic life forms and life histories, annuals are more represented both among species invading from Europe compared to those invading Europe and from the Old World compared to those invading the Old World. Further, herbaceous species are more represented among species invading from Europe. At the same time, European annual species such as Bromus sterilis, B. tectorum, Erodium cicutarium or Trifolium subterraneum have been recognized as aggressive and widespread weeds invading grasslands world-wide. Native species of grasslands outside Europe may not be well adapted to compete with annual species as it has been documented on the example of European annual grasses (Bromus sterilis and B. tectorum) invading grasslands in North America, originally dominated by native perennials (Mack, 1989).

The relative overrepresentation of species from wetland habitats invading to the Old World than vice-versa may be associated with frequent introductions of wetland ornamentals to Europe, such as Acer negundo, Baccharis halimifolia, Gunnera tinctoria or Thespesia populnea, but this pattern is not as convincing as the disproportional representation of grasslands among the native-range habitats of species invading from versus to Europe.

Forests, riparian habitats, grasslands and man-made habitats appear to be the most substantial donors of invasive plant species world-wide. In contrast, relatively few invasive species appear to have recruited from dryland, saline and aquatic habitats. In general, stress factors such as drought, extreme temperatures, high salinity or low nutrient levels are considered to lower the invasibility of habitats (Alpert et al., 2000), which may be at least partly related to the fact that few invaders are adapted to stressful environments in their native ranges (Te Beest et al., 2013). On the other hand, the relatively small area of some specific habitat types, such as saline habitats, is also a likely cause of small numbers of invasive aliens recruited from such habitats. However, these patterns need to be interpreted very carefully. First, we do not have any rigorous data on the relative areas of particular habitat types in the native ranges. It is possible that species from some habitats frequently invade not because of advantageous adaptations, but simply because habitats such as forests and grasslands occupy the largest areas in their native range, and therefore are likely to harbour the largest species pools and provide the largest numbers of invasive species. 
Further, there are overlaps between the habitat types as defined in this study. For example, riparian habitats are usually composed of a mosaic of moist forests, scrub, grasslands and wetlands. For this reason, most species are affiliated to more than one habitat type, so the sum of species-habitat affiliations in both native and invaded ranges greatly exceeds the total number of selected species. Even though this makes the interpretation of native-range habitat patterns difficult, it basically reflects the fact that successful invaders occupy large areas in the native ranges, are adapted to a wide range of climatic and ecological conditions and therefore also occupy several habitat types in the native range (Hejda et al., 2009; Pyšek et al., 2009; Kalusová et al., 2013). Information on biomass or abundance of species within habitat types would allow for more precise affiliations of species to particular habitats. Therefore, in the future studies, it may be worth recording not only the presence of species within habitats, but also estimate their relative abundances or biomass.

Although invasive plant species typically invade the same or similar habitats as they occupy in their native range, it is apparent that many species also invade different habitats. However, invaded habitats are likely to be described in more detail in invasion literature than the native-range habitats because of the generally better information on species from their invaded rather than native range (Parker et al., 2013). Therefore, the reported expansions into new habitats associated with the invasion may be, to a large degree, an artefact due to biased data.

Grasslands were identified as most disproportionally represented when comparing native and invaded-range habitats, with underrepresentation in the native and overrepresentation in the invaded ranges. Grasslands are invaded by many species that originate from other habitat types: forests (28 species), scrub (22 species) or sandy habitats (21 species), although especially the latter can also include grasslands. The shifts in habitat preference or tolerance associated with invasions have been recognized in previous studies (e.g. Hejda et al., 2009; Moloney et al., 2009), and various explanations have been suggested (Molina-Montenegro et al., 2011). In some cases, rapid evolution in the invaded range may occur, leading to changes in habitat preference or tolerance (Reznick \& Ghalambdor, 2001; Lee, 2002; Lambrinos, 2004; Lavergne et al., 2009; Novy et al., 2013). At the same time, genetic variability and phenotypic plasticity in the native range can lead to the invasive populations occupying partly different niches and habitats in the invaded ranges (Geng et al., 2007), which is especially apparent when invasive populations are subjected to fewer pathogens and herbivores (DeWalt et al., 2004; Hornoy et al., 2011; Kellner et al., 2011), use 'novel weapons' (i.e. new ways to use available resources or compete with other species; Callaway et al., 2008), or experience less intensive interspecific competition (Ridenour et al., 2008). Further, species may not always grow in the optimal conditions in the native range and can be thus more succesful in different habitats in the invaded range. In some cases, the optimal habitat of a given species in the native range may be occupied by strong competitors, hence its occurrence is more pronounced in another habitat that is less suitable in terms of the species' ecological requirements.

As already mentioned, there is an overlap among the habitat types used in this study, and, moreover, some of the habitat types studied here may actually represent various successional phases of vegetation. For example, succession from grassland to scrub, open woodland and forest can occur within a few decades in the same place (Prach \& Pyšek, 2001). Riparian habitats typically represent a mosaic of vegetation types, ranging from riparian grasslands to riparian forests. This raises a question whether the native/ invaded-range transitions among these habitat types really mean that a particular invasive species is able to occupy different vegetation types in the invaded range or whether it is just adapted to thrive in a broad range of successional stages, ranging from open habitats such as grasslands to forests. This idea is at least partly supported by the fact that species recruited from grasslands frequently invade both riparian habitats and open woodlands, while forest species frequently invade riparian habitats and grasslands as well. Species from man-made habitats often invade both riparian habitats and forests. However, in the case of forests, it is questionable whether species recruited from man-made habitats really invade closed undisturbed forests or whether they thrive in disturbed or at least partially open places. It is commonly observed that synanthropic species do not usually invade pristine woodlands; instead, they establish at disturbed or otherwise human-influenced sites (Alpert et al., 2000). Humans can act as a vector for the propagules of alien plants, while the human-induced disturbances can create sites suitable for the invasion, with lower intensity of competition by native vegetation (Williamson et al., 2005; Hufbauer et al., 2011). On the other hand, even habitats with limited human impact can be invaded, as demonstrated by Martin et al. (2009). However, it is apparent from these data that species recruited from open habitats in their native ranges, such as grasslands, are able to invade semi-closed vegetation, such as open forests. Conversely, species from closed habitats (forests) frequently invade open vegetation, especially grasslands. The level of invasion of individual invaded-range habitats may also be biased by differences in propagule pressure of alien species, which are mostly related to human activity within a given habitat. In general, manmade habitats reveal high levels of invasion, which may be related more to the human-assisted propagule import than to the invasive species' adaptations from the native ranges (Chytrý et al., 2008a,b).

Unfortunately, most of the descriptions of both native and invaded-range habitats do not allow for addressing the correspondence between them in more detail. However, it has been documented that species broaden their native-range ecological niche during the process of invasion (e.g. Essl et al., 2009) and it is likely that some species really invade other habitat types than those occupied in the native range. 


\section{ACKNOWLEDGEMENTS}

This research was supported by long-term research development project no. RVO 67985939 (Academy of Sciences of the Czech Republic) and institutional resources of the Ministry of Education, Youth and Sports of the Czech Republic. M.H. and P.P. were supported by grant no. P505/11/1112 (Czech Science Foundation), M.C., J.P. and P.P. by the Centre of Excellence PLADIAS (Czech Science Foundation; 14-36079G), and P.P. acknowledges support from the Praemium Academiae award from the Academy of Sciences of the Czech Republic. We thank Christina Alba for comments and improving our English.

\section{REFERENCES}

Affre, L., Suehs, C.M., Charpentier, S., Vilà, M., Brundu, G., Lambdon, P., Traveset, A. \& Hulme, P.E. (2010) Consistency in the habitat degree of invasion for three invasive plant species across Mediterranean islands. Biological Invasions, 12, 2537-2548.

Alpert, P., Cone, E. \& Holzapfel, C. (2000) Invasiveness, invasibility and the role of environmental stress in the spread of non-native plants. Perspectives in Plant Ecology, Evolution and Systematics, 3, 52-66.

Callaway, R.M., Cipollini, D., Barto, K., Thelen, G.C., Hallett, S.G., Prati, D., Stinson, K. \& Klironomos, J. (2008) Novel weapons: invasive plant suppresses fungal mutualists in America but not in its native Europe. Ecology, 89, 1043-1055.

di Castri, F. (1989) History of biological invasions with special emphasis on the Old World. Biological invasions: a global perspective (ed. by J.A. Drake, H.A. Mooney, F. di Castri, R.H. Groves, F.J. Kruger, M. Rejmánek and M. Williamson), pp. 1-30. John Wiley and Sons, Chichester.

Catford, J.A., Vesk, P.A., Richardson, D.M. \& Pyšek, P. (2012) Quantifying levels of biological invasion: towards the objective classification of invaded and invasible ecosystems. Global Change Biology, 18, 44-62.

Chytrý, M., Pyšek, P., Tichý, L., Knollová, I. \& Danihelka, J. (2005) Invasions by alien plants in the Czech Republic: a quantitative assessment across habitats. Preslia, 77, 339-354.

Chytrý, M., Jarošík, V., Pyšek, P., Hájek, O., Knollová, I., Tichý, L. \& Danihelka, J. (2008a) Separating habitat invasibility by alien plants from the actual level of invasion. Ecology, 89, 1541-1553.

Chytrý, M., Maskell, L.C., Pino, J., Pyšek, P., Vilà, M., Font, X. \& Smart, S.M. (2008b) Habitat invasions by alien plants: a quantitative comparison among Mediterranean, subcontinental and oceanic regions of Europe. Journal of Applied Ecology, 45, 448-458.

Crawley, M.J. (2007) The $R$ book. John Wiley \& Sons Ltd, Chichester, UK.

D’Antonio, C.M., Dudley, T.L. \& Mack, M. (1999) Disturbance and biological invasions: direct effects and feedbacks.
Ecosystems of the world: ecosystems of disturbed ground (ed. by L.R. Walker), pp. 413-452. Elsevier, Amsterdam.

Davis, M.A. \& Pelsor, M. (2001) Fluctuating resources lead to predictable changes in competition and invasibility. Ecology Letters, 4, 421-428.

Davis, M.A., Grime, J.P. \& Thompson, K. (2000) Fluctuating resources in plant communities: a general theory of invasibility. Journal of Ecology, 88, 528-534.

DeWalt, S., Denslow, J.S. \& Ickes, K. (2004) Natural enemyrelease facilitates habitat expansion of the invasive tropical shrub Clidemia hirta. Ecology, 85, 471-483.

Essl, F., Dullinger, S. \& Kleinbauer, I. (2009) Changes in the spatio-temporal patterns and habitat preferences of Ambrosia artemisiifolia during its invasion of Austria. Preslia, 81, 119-133.

Geng, Y.P., Pan, X.Y., Xu, C.Y., Zhang, W.J., Li, B., Chen, J.K., Lu, B.R. \& Song, Z.P. (2007) Phenotypic plasticity rather than locally adapted ecotypes allows the invasive alligator weed to colonize a wide range of habitats. Biological Invasions, 9, 245-256.

Gentry, A.H. (1982) Patterns of neotropical plant species diversity. Evolutionary Biology, 15, 1-84.

Hejcman, M., Hejcmanová, P., Pavlů, V. \& Beneš, J. (2013) Origin and history of grassland in Central Europe - a review. Grass and Forage Science, 68, 345-363.

Hejda, M. (2013) Do species differ in their ability to coexist with the dominant alien Lupinus polyphyllus? A comparison between two distinct invaded ranges and a native range. NeoBiota, 17, 39-55.

Hejda, M., Pyšek, P., Pergl, J., Sádlo, J., Chytrý, M. \& Jarošík, V. (2009) Invasion success of alien plants: do habitat affinities in the native distribution range matter? Global Ecology and Biogeography, 18, 372-382.

Higgins, S.I. \& Richardson, D.M. (1998) Pine invasions in the southern hemisphere: modelling interactions between organism, environment and disturbance. Plant Ecology, 135, 79-93.

Hobbs, R.J. \& Huenneke, L.F. (1992) Disturbance, diversity, and invasion: implications for conservation. Conservation Biology, 6, 324-337.

Hornoy, B., Tarayre, M., Hervé, M., Gigord, L. \& Atlan, A. (2011) Invasive plants and enemy release: evolution of trait means and trait correlations in Ulex europaeus. PLoS ONE, 6, e26275.

Hufbauer, R.A., Facon, B., Ravigne, V., Turgeon, J., Foucaud, J., Lee, C.E., Rey, O. \& Estoup, A. (2011) Anthropogenically induced adaptation to invade (AIAI): contemporary adaptation to human-altered habitats within the native range can promote invasions. Evolutionary Applications, 5, 89-101.

Kalusová, V., Chytrý, M., Kartesz, J.T., Nishino, M. \& Pyšek, P. (2013) Where do they come from and where do they go? European natural habitats as donors of invasive alien plants globally. Diversity and Distributions, 19, 199-214.

Kellner, J.R., Asner, G.P., Kinney, K.M., Loarie, S.R., Knapp, D.E., Kennedy-Bowdoin, T., Questad, E.J., Cordell, S. \& 
Thaxton, J.M. (2011) Remote analysis of biological invasion and the impact of enemy release. Ecological Applications, 21, 2094-2104.

Kubát, K., Hrouda, L., Chrtek Jr., J., Kaplan, Z., Kirschner, J. \& Štepánek, J. (Eds) (2002) Key to the Flora of the Czech Republic. Academia, Prague. (In Czech.)

Lambrinos, J.G. (2004) How interactions between ecology and evolution influence contemporary invasion dynamics. Ecology, 85, 2061-2070.

Lavergne, S., Muenke, N.J. \& Molofsky, J. (2009) Genome size reduction can trigger rapid phenotypic evolution in invasive plants. Annals of Botany, 105, 109-116.

Lee, C.A. (2002) Evolutionary genetics of invasive species. Trends in Ecology \& Evolution, 17, 386-391.

Mack, R.N. (1989) Temperate grasslands vulnerable to plant invasions: characteristics and consequences. Biological invasions. A global perspective (ed. by J.A. Drake, H.A. Mooney, F. di Castri, R.H. Groves, F.J. Kruger, M. Rejmánek and M. Williamson), pp. 155-179. John Wiley \& Sons, Chichester.

Martin, P.H., Canham, C.D. \& Marks, P.L. (2009) Why forests appear resistant to exotic plant invasions: intentional introductions, stand dynamics, and the role of shade tolerance. Frontiers in the Ecology and the Environment, 7, 142-149.

Moles, A.T., Flores-Moreno, H., Bonser, S.P. et al. (2012) Invasions: the trail behind, the path ahead, and a test of a disturbing idea. Journal of Ecology, 100, 116-127.

Molina-Montenegro, M.A., Quiroz, C.L., Torres-Diaz, C. \& Atala, C. (2011) Functional differences in response to drought in the invasive Taraxacum officinale from native and introduced alpine habitat ranges. Plant Ecology and Diversity, 4, 37-44.

Moloney, K.A., Knaus, K. \& Dietz, H. (2009) Evidence for a shift in life-history strategy during the secondary phase of a plant invasion. Biological Invasions, 11, 625-634.

Mooney, H.A. \& Drake, J.A. (1989) Biological invasions: a SCOPE program overview. Biological invasions: a global perspective (ed. by J.A. Drake, H.A. Mooney, F. di Castri, R.H. Groves, F.J. Kruger, M. Rejmánek and M. Williamson), pp. 491-506. John Wiley and Sons, Chichester.

Novy, A., Flory, S.L. \& Hartman, J.M. (2013) Evidence for rapid evolution of phenology in an invasive grass. Journal of Evolutionary Ecology, 26, 443-450.

Otte, A., Eckstein, R.L. \& Thiele, J. (2007) Heracleum mantegazzianum in its primary distribution range of the Western Greater Caucasus. Ecology and management of giant hogweed (Heracleum mantegazzianum) (ed. by P. Pyšek, M.J.W. Cook, W. Nentwig and H.P. Ravn), pp. 20-42. CABI International Publishing, Athenaeum Press, Gateshead, UK.

Parker, J.D., Torchin, M.E., Hufbauer, R.A. et al. (2013) Do invasive species perform better in their new ranges? Ecology, 94, 985-994.

Pergl, J., Pyšek, P., Perglová, I. \& Jarošík, V. (2012) Low persistence of a monocarpic invasive plant in historical sites biases our perception of its actual distribution. Journal of Biogeography, 39, 1293-1302.

Prach, K. \& Pyšek, P. (2001) Using spontaneous succession for restoration of human-disturbed habitats: experience from central Europe. Ecological Engineering, 17, 55-62.

Pyšek, P. (1998) Is there a taxonomic pattern to plant invasions? Oikos, 82, 282-294.

Pyšek, P. \& Chytrý, M. (2014) Habitat invasion research: where vegetation science and invasion ecology meet. Journal of Vegetation Science, 25, 1181-1187.

Pyšek, P., Jarošík, V., Pergl, J., Randall, R., Chytrý, M., Kühn, I., Tichý, L., Danihelka, J., Chrtek, J. Jr \& Sádlo, J. (2009) The global invasion success of Central European plants is related to distribution characteristics in their native range and species traits. Diversity and Distributions, 15, 891-903.

Pyšek, P., Bacher, S., Chytrý, M., Jarošík, V., Wild, J., Celesti-Grapow, L., Gassó, N., Kenis, M., Lambdon, P.W., Nentwig, W., Pergl, J., Roques, A., Sádlo, J., Solarz, W., Vilà, M. \& Hulme, P.E. (2010a) Contrasting patterns in the invasions of European terrestrial and freshwater habitats by alien plants, insects and vertebrates. Global Ecology and Biogeography, 19, 317-331.

Pyšek, P., Jarošík, V., Hulme, P.E. et al. (2010b) Disentangling the role of environmental and human pressures on biological invasions across Europe. Proceedings of the National Academy of Sciences of USA, 107, 12157-12162.

Pyšek, P., Chytrý, M., Pergl, J., Sádlo, J. \& Wild, J. (2012) Plant invasions in the Czech Republic: current state, introduction dynamics, invasive species and invaded habitats. Preslia, 84, 576-630.

R Development Core Team (2011) R: a language and environment for statistical computing. R Foundation for Statistical Computing, Vienna. http://www.R-project.org. (version 3.0.2)

Reznick, D.N. \& Ghalambdor, C.K. (2001) The population ecology of contemporary adaptations: what empirical studies reveal about the conditions that promote adaptive evolution. Genetica, 112, 183-198.

Ridenour, W.M., Vivanco, J.M., Feng, Y., Horiuchi, J. \& Callaway, R.M. (2008) No evidence for tradeoffs: Centaurea plants from America are better competitors and defenders than plants from the native range. Ecological Monographs, 78, 369-386.

Schlaepfer, M.A., Sherman, P.W., Blossey, B. \& Runge, M.C. (2005) Introduced species as evolutionary traps. Ecology Letters, 8, 241-246.

Seastedt, T.R. \& Pyšek, P. (2011) Mechanisms of plant invasions of North American and European grasslands. Annual Reviews of Ecology, Evolution and Systematics, 42, 133-153.

Stohlgren, T.J., Binkley, D., Chong, G.W., Kalkhan, M.A., Schell, L.D., Bull, K.A., Otsuki, Y., Newman, G., Bashkin, M. \& Son, Y. (1999) Exotic plant species invade hot spots of native plant diversity. Ecological Monographs, 69, 25-46. 
Stohlgren, T., Jarnevich, C., Chong, G.W. \& Evangelista, P.H. (2006) Scale and plant invasions: a theory of biotic acceptance. Preslia, 78, 405-426.

Stohlgren, T.J., Pyšek, P., Kartesz, J., Nishino, M., Pauchard, A., Winter, M., Pino, J., Richardson, D.M., Wilson, J.R.U., Murray, B.R., Phillips, M.L., Ming-yang, L., Celesti-Grapow, L. \& Font, X. (2011) Widespread plant species: natives versus aliens in our changing world. Biological Invasions, 13, 1931-1944.

Te Beest, M., Elschot, K., Olff, H. \& Etienne, R.S. (2013) Invasion success in a marginal habitat: an experimental test of competitive ability and drought tolerance in Chromolaena odorata. Plos One, 8, e68274.

Thuiller, W., Richardson, D.M., Pyšek, P., Midgley, G.F., Hughes, G.O. \& Rouget, M. (2005) Niche-based modelling as a tool for predicting the risk of alien plant invasions at a global scale. Global Change Biology, 11, 2234-2250.

Vilà, M., Pino, J. \& Font, X. (2007) Regional assessment of plant invasions across different habitat types. Journal of Vegetation Science, 18, 35-42.

Weber, E. (2003) Invasive plant species of the world: a reference guide to environmental weeds. CABI Publishing, Wallingford, UK.

Williams, J.A. \& West, C.J. (2000) Environmental weeds in Australia and New Zealand: issues and approaches to management. Austral Ecology, 25, 425-444.

Williamson, M., Pyšek, P., Jarošík, V. \& Prach, K. (2005) On the rates and patterns of spread of alien plants in the Czech Republic, Britain, and Ireland. Ecoscience, 12, 424-433.

\section{SUPPORTING INFORMATION}

Additional Supporting Information may be found in the online version of this article:

Appendix S1 Native- and invaded-range habitat descriptions, affiliations into habitat types and geographical delimitations of native and invaded ranges.

\section{BIOSKETCHES}

Martin Hejda, Jan Pergl and Petr Pyšek are members of a research team focusing on various aspects of biological invasions, such as theoretical framework of invasion process, species invasiveness, habitat invasibility, impacts of invasive plants, dynamics of alien species' spread and macroecological patterns of biological invasions. They were involved in several European Union projects addressing biological invasions. Milan Chytrý is interested in plant community ecology including community context of plant invasions, vegetation classification and diversity patterns in plant communities.

The Authors' contributions: $\mathrm{MH}$ together with PP and JP conceived the idea, $\mathrm{MH}$ analysed the data and wrote the manuscript, MC participated in habitat interpretation, all coauthors discussed and edited the manuscript.

Editor: Jeffrey Diez 